\title{
The Continental Shelf of Antarctica: Implications of the Requirement to Make a Submission to the CLCS under Article 76 of the LOS Convention
}

\author{
Alex G. Oude Elferink ${ }^{*}$ \\ Netherlands Institute for the Law of the Sea, \\ Utrecht University, The Netherlands
}

\begin{abstract}
This article looks at the question of how the obligation of states parties to the United Nations Convention on the Law of the Sea to submit information on the outer limit of their continental shelf to the Commission on the Limits of the Continental Shelf and the regime established by the Antarctic Treaty can be reconciled. Under the latter Treaty states have 'agreed to disagree' about the legal status of Antarctica. The establishment of an outer limit of the continental shelf on the basis of the recommendations of the Commission on the Limits of the Continental Shelf would pose a threat to this agreement to disagree as it would recognise the existence of coastal states and maritime zones. The article sets out the options of the states involved to deal with this issue. It is concluded that there are a number of approaches which safeguard the rights of coastal states under the United Nations Convention on the Law of the Sea and the agreement to disagree of the Antarctic Treaty.
\end{abstract}

\section{Introduction}

The Antarctic continent and the adjacent sea areas are governed by a special treaty regime. Reconciling this regime with the general international law of the sea has posed considerable challenges. At present, such a reconciliation has to be found in respect of the requirements for the establishment of the outer limits of

* An earlier version of this article was presented at the Southern Ocean Law of the Sea and Maritime Disputes Workshop, Faculty of Law, University of Sydney, Australia, 19 October 2001. The author would like to thank the participants of this workshop, and L.D.M. Nelson, C. Hernandez Salas, H.M. Dotinga and E.J. Molenaar and others for their comments on an earlier version of this article.

THE INTERNATIONAL JOURNAL OF MARINE AND COASTAL LAW, Vol 17, No 4

(C) Kluwer Law International, 2002 
the continental shelf under the United Nations Convention on the Law of the Sea (LOS Convention). ${ }^{1}$

The Antarctic Treaty $^{2}$ of 1959 provides the basis for co-operation on the Antarctic continent and the waters surrounding it. The Treaty has allowed states to co-operate, while preserving their different views over the status of Antarctica under international law. Instruments which have been adopted after the Antarctic Treaty entered into force ${ }^{3}$ have built on the compromise over the status of Antarctica contained in the Treaty. These instruments have taken into account developments in the law of the sea in defining their area of application.

Within the ATS, three groups of states can be distinguished as far as the territorial status of Antarctica and maritime jurisdiction are concerned. Seven states, which are also referred to as the claimant states, have laid claim to parts of the Antarctic continent. This concerns Argentina, Australia, Chile, France, New Zealand, Norway and the United Kingdom. Claimant states consider that their claims over Antarctica include the adjacent maritime zones, as they have evolved under the law of the sea. The claimant states have sought to see this view reflected in instruments that have been negotiated in the framework of the ATS. They have also legislated unilaterally on the maritime zones of their Antarctic territories or taken other actions in this respect. The United States and the Russian Federation have not made claims to any part of the Antarctic territory, but have maintained a basis for such a claim and have not recognised the claims of the claimant states. Because these two states have maintained a basis for a claim (and the US also for its political weight), they have a particular interest in any development in respect of the status of Antarctica. Other states, both within and outside the ATS, in general have not recognised the territorial claims to the Antarctic continent and appurtenant maritime zones. All states co-operating in the framework of the ATS have an interest in maintaining the status quo in respect of the compromise over sovereignty contained in the Antarctic Treaty as it is a cornerstone of the regime's stability.

The accommodation of the positions of claimant states and non-claimant states in respect of the status of the Antarctic continent and the waters surrounding it has to a large extent been achieved by what has been termed by authors as the "bifocal approach" or "constructive ambiguity". ${ }^{4}$ These terms are

1 Concluded on 10 December 1982, entered into force on 16 November 1994 ((1833) United Nations Treaty Series 396); and Agreement Relating to the Implementation of Part XI of the United Nations Convention on the Law of the Sea of 10 December 1982, concluded on 28 July 1994, entered into force on 28 July 1996 ((1836) UNTS 41).

2 Concluded on 1 December 1959, entered into force on 23 June 1961 (402 UNTS 71).

3 The totality of these instruments is also referred to as the Antarctic Treaty System (ATS). The relevant ATS instruments are further discussed in the section "Maritime Zones and the Antarctic Treaty System" below.

4 See the references in F. Orrego Vicuna, "The Law of the Sea and the Antarctic Treaty System: New Approaches to Offshore Jurisdiction" in C.C. Joyner and S.K. Chopra (eds.), The Antarctic Legal Regime (Dordrecht, Martinus Nijhoff Publishers, 1988), pp. 97-127 at p. 111. 


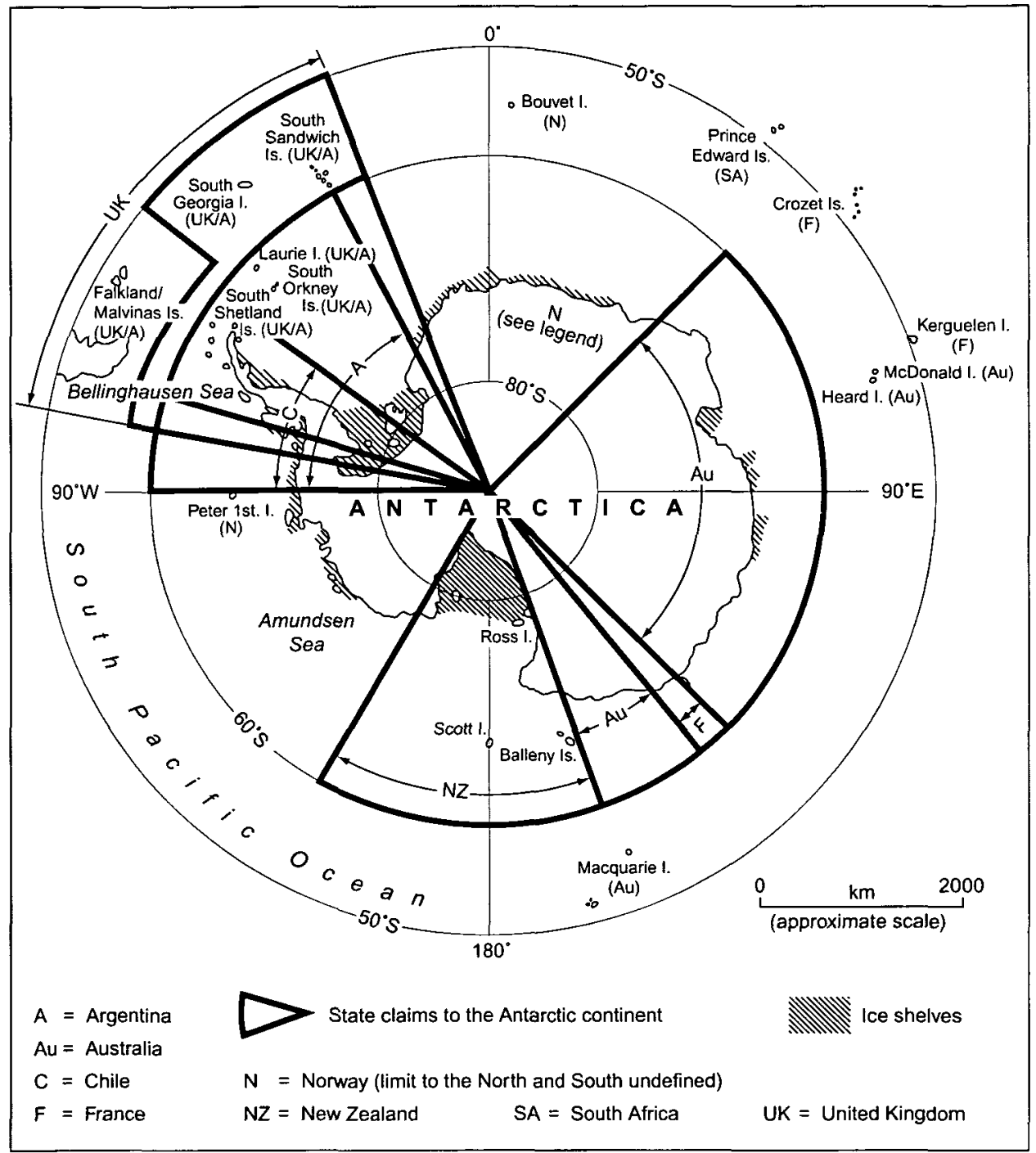

Figure 1 The Political Geography of Antarctica

(C) Kluwer Law International, 2002 
used to refer to the fact that certain provisions in the Antarctic Treaty and other ATS instruments allow claimant states and non-claimant states to consider that they reflect their respective positions concerning the status of Antarctica and the surrounding waters. This also concerns recognition of the fact that certain islands to the north of the area of application of the Antarctic Treaty can generate maritime zones extending into this area.

Any step which would threaten to destabilise "constructive ambiguity" would negatively impact upon co-operation within the ATS. One obligation of coastal states under the LOS Convention seems to have the potential to pose a threat to "constructive ambiguity". This concerns the obligation of coastal states to make a submission to the Commission on the Limits of the Continental Shelf (CLCS) in case their continental shelf extends beyond 200 nautical miles from the baseline from which the breadth of the territorial sea is measured. ${ }^{5}$ The LOS Convention requires that a state submits information on the outer limit of such continental shelf areas to the CLCS within 10 years after entry into force for that state. ${ }^{6}$ Recommendations of the CLCS on the outer limit of the continental shelf of an Antarctic territory would imply recognition of the position of the claimant states that they are coastal states and can validly establish maritime zones.

This article intends to identify the possibilities of dealing with submissions concerning the continental shelf in Antarctica in such a way that:

- "constructive ambiguity" under the ATS is not jeopardised; and

- the rights of claimant states in respect of the establishment of the outer limit of the continental shelf under the LOS Convention are safeguarded.

The first section indicates how states have dealt with the definition of maritime zones in Antarctica. This is followed by an analysis of the relevant provisions of the LOS Convention and the Rules of Procedure adopted by the CLCS. ${ }^{7}$ Annex I to the Rules of Procedure deals explicitly with territorial and maritime disputes in relation to submissions to the Commission and as such is of relevance for the continental shelf in Antarctica. ${ }^{8}$

The next section gives a short description of the political geography of Antarctica, including some information on the extent of the continental shelf. Broadly speaking, states will have to take into account the interaction between Article 76 of the LOS Convention and the ATS in two cases. Apart from territory within the Antarctic Treaty area, there are also a number of islands to the north of this area, whose continental shelf beyond 200 nautical miles extends

On the CLCS see further the text at notes 48 and 49 .

LOS Convention, Annex II, Art. 4.

The present version of the Rules of Procedure of the CLCS are contained in CLCS/3/Rev. 3 of 6 February 200I (available at www.un.org/Depts/los/clcs_new/commission_documents.htmRules (last accessed on 12 July 2002)).

8 Rule 45 and Annex I to the Rules of Procedure are included in an appendix to this article. 
into the Treaty area. Although the focus of this article is on the former situation, which is more complex, some attention will also be given to the second case.

After the presentation of the political geography of Antarctica, the discussion turns to the actions that have been taken by Antarctic claimant states and the options they and other states have to deal with the establishment of the outer limit of the continental shelf under Article 76 of the LOS Convention. It cannot be excluded that the CLCS may not be in a position to formulate recommendations on the continental shelf in Antarctica for an undetermined period of time. The article discusses the consequences of the absence of an outer limit established on the basis of the recommendations of the CLCS. States can be expected to take into account such consequences in deciding how to approach the requirement concerning submissions under Article 76 of the LOS Convention. The conclusion of the article recapitulates its main findings and suggests what solutions are feasible.

\section{Maritime Zones and the Antarctic Treaty System}

The Antarctic Treaty was negotiated primarily to regulate the status of and activities on the Antarctic continent, but it also dealt with the status of the seas surrounding Antarctica. The need to regulate specific activities in the Southern Ocean has led to a continued concern for the definition of the maritime spaces to which ATS instruments apply. This happened in a period in which the law of the sea was being transformed through the creation of new maritime zones, such as the exclusive economic zone (EEZ) and the international sea-bed area (Area) and the redefinition of the outer limit of other zones, in particular the continental shelf. These developments are reflected in the practice of the states collaborating within the framework of the ATS.

Before looking at specific instances in which instruments adopted in the framework of the ATS have dealt with the definition of maritime zones, one preliminary observation is called for. The present analysis does not purport to reach a conclusion on the validity of the interpretations of claimant states and non-claimant states in respect of provisions in ATS instruments dealing with maritime zones. ${ }^{9}$ Such an analysis is not required in connection with the present discussion of the implications of Article 76 of the LOS Convention for Antarctica. In view of the importance of "constructive ambiguity" for the

This issue has been discussed extensively in the literature. See e.g. C.C. Joyner, Antarctica and the Law of the Sea (Dordrecht, Martinus Nijhoff Publishers, 1992); F. Orrego Vicuna, note 4 above; T. Scovazzi, "The Antarctic Treaty System and the New Law of the Sea: Selected Questions" in F. Francioni and T. Scovazzi (eds.), International Law for Antarctica (The Hague, Kluwer Law International, 1997), pp. 377-394; D. Vidas, "The Antarctic Treaty System and the Law of the Sea: A New Dimension Introduced by the Protocol" in O.S. Stokke and D. Vidas (eds.), Governing the Antarctic; The Effectiveness and Legitimacy of the Antarctic Treaty System (Cambridge, Cambridge University Press, 1996), pp. 6I-90; P. Vigni, “Antarctic Maritime Claims: 'Frozen Sovereignty' and the Law of the Sea" in A.G. Oude Elferink and D.R. Rothwell (eds.), The Law of Sea and Polar Maritime Delimitation and Jurisdiction (The Hague, Martinus Nijhoff Publishers, 2001), pp. 85-104. 
stability of the ATS, it can in any case be expected to remain in place as long as the ATS is effective.

An analysis of practice concerning Antarctic maritime zones is of significance for a number of reasons. Claimant states and non-claimant states will wish to prevent any approach under Article 76 of the LOS Convention that may seem to contradict or weaken their position on the presence of maritime zones in Antarctica. At the same time, solutions that have been applied in the past to create "constructive ambiguity" may provide indications of how states may deal with the problems posed by the implementation of Article 76 of the LOS Convention. Apart from provisions in ATS instruments, the practice of claimant states in defining maritime zones of their Antarctic territories and the reactions of other states is of relevance in this connection.

The Antarctic Treaty itself contains two provisions that have a direct bearing on the question of maritime zones in Antarctica. Article IV(2) provides inter alia that "[n]o new claim, or enlargement of an existing claim, to territorial sovereignty in Antarctica shall be asserted while the present Treaty is in force". It has been argued that this provision would prevent claimant states from asserting the existence of maritime zones, at least to the extent that these did not already exist by the time the Antarctic Treaty entered into force in 1961. To counter this argument it has been submitted that Article IV is concerned with claims to territorial sovereignty and does not concern maritime zones which are appurtenant to these territories. ${ }^{10}$

The Antarctic Treaty applies to the area south of $60^{\circ} \mathrm{S}$, including all ice shelves, but at the same time provides that "nothing in the present Treaty shall prejudice or in any way affect the rights, or the exercise of the rights, of any State under international law with regard to the high seas within that area"." This reference to the high seas has been interpreted to support the position that all the waters surrounding Antarctica are included in the high seas. The countervailing argument in this case is that Article VI only safeguards the rights of states in the high seas, without defining the extent of the high seas. ${ }^{12}$

On the interpretation of Article IV of the Antarctic Treaty on this point, see e.g. M.T. Infante, "The Continental Shelf of Antarctica: Legal Implications for a Regime on Mineral Resources" in F. Orrego Vicuña (ed.), Antarctic Resource Policy; Scientific, Legal and Political Issues (Cambridge, Cambridge University Press, 1983), pp. 253-264, at pp. 254-256; S.B. Kaye, "The Outer Continental Shelf in the Antarctic" in A.G. Oude Elferink and D.R. Rothwell (eds.), note 9 above, pp. 125-137, at pp. 133-136; T. Scovazzi, note 9 above, pp. 383-385; G.D. Triggs, "The Antarctic Treaty System: Some Jurisdictional Problems" in G.D. Triggs (ed.), The Antarctic Treaty Regime; Law, Environment and Resources (Cambridge, Cambridge University Press, 1987), pp. 90-91; A. Van der Essen, "The Arctic and Antarctic Regions" in R. Dupuy and D. Vignes (eds.), $A$ New Handbook on the Law of the Sea (Dordrecht, Martinus Nijhoff Publishers, 1991), pp. 525-560, at pp. 549-550; P. Vigni, note 9 above, pp. 93-94.

11 Antarctic Treaty, Art. VI.

12 On the interpretation of Art. VI of the Antarctic Treaty on this point, see e.g. M.T. Infante, note 10 above, pp. 93-94; T. Scovazzi, note 9 above, pp. 386-387; A. Van der Essen, note 10 above, pp. 550-551; P. Vigni, note 9 above, pp. 93-94. 
The issue of maritime jurisdiction is also addressed in the Convention on the Conservation of Antarctic Seals (CCAS) of $1972 .{ }^{13}$ The Convention defines its area of application as the seas south of $60^{\circ} \mathrm{S}$ and provides that the contracting parties affirm the provisions of Article IV of the Antarctic Treaty. ${ }^{14}$ Jurisdiction in respect of activities regulated by CCAS is to be exercised by states in respect of their nationals or vessels flying their flag. ${ }^{15}$ Thus, jurisdiction under CCAS is based on the regime of the high seas and does not take into account the legal regime applicable in coastal state maritime zones. This should not be taken as prejudging the position of claimant states in respect of maritime zones in view of Article IV of the Antarctic Treaty, which is explicitly reaffirmed in CCAS. A number of claimant states have nonetheless explicitly indicated that CCAS does not impair the rights of the contracting parties as regards maritime jurisdiction. ${ }^{16}$ The Soviet Union, in a reaction to the Argentine declaration in this respect, indicated that it considered the reservation on maritime jurisdiction to be in conflict with Article IV(2) of the Antarctic Treaty. ${ }^{17}$

The issue of maritime jurisdiction had to be addressed again in the negotiations on a convention on Antarctic marine living resources, which were initiated in the second half of the 1970s. At that time, the legality of extending coastal state jurisdiction over marine living resources to 200 nautical miles had become generally accepted. This development was reflected in the practice of some claimant states in respect of their Antarctic territories. ${ }^{18}$ Some proposals made during the negotiations would have implied the recognition of rights of the claimant states in the waters around Antarctica. ${ }^{19}$ The Convention on the Conservation of Antarctic Marine Living Resources ${ }^{20}$ (CCAMLR) resolves this issue by making Articles IV and VI of the Antarctic Treaty applicable between the contracting parties to CCAMLR, whether or not they are parties to the Antarctic Treaty. ${ }^{21}$ However, this provision only applies to the Antarctic Treaty area,,$^{22}$ and not to areas to the north of $60^{\circ} \mathrm{S}$, which are also included in the scope of application of CCAMLR. ${ }^{23}$ Paragraph 2 of Article IV of CCAMLR explicitly

\footnotetext{
Concluded on 1 June 1972, entered into force on 11 March 1978 (1080 UNTS 175).

Art. 1(1).

Art. 2.

See F. Orrego Vicuña, note 4 above, pp. 106-107.

See ibid., p. 107.

See ibid., pp. 107-108.

See $i b i d .$, p. 111 .

Concluded on 20 May 1980, entered into force on 7 April 1982 (1329 UNTS 47).

CCAMLR, Art. IV(1).

Ibid.

3 Art. I(1) of CCAMLR provides that the Convention "applies to the Antarctic marine living resources of the area south of 60 South latitude and to the Antarctic marine living resources of the area between that latitude and the Antarctic Convergence which form part of the Antarctic marine ecosystem". The Antarctic Convergence is defined by a set of geographical coordinates in Art. I(4) of CCAMLR.
} 
addresses the issue of maritime jurisdiction. Its subparagraphs (b) and (c), which are most relevant in this respect provide:

"2. Nothing in this Convention and no acts or activities taking place while the present Convention is in force shall:

[...]

b. be interpreted as a renunciation or diminution by any Contracting Party of, or as prejudicing, any right or claim or basis of claim to exercise coastal state jurisdiction under international law within the area to which this Convention applies;

c. be interpreted as prejudicing the position of any Contracting Party as regards its recognition or non-recognition of any such right, claim or basis of claim;

[... ]"

This provision is not only relevant for maritime jurisdiction in the Antarctic Treaty area, but also for areas to the north of $60^{\circ} \mathrm{S}$ to which CCAMLR applies. There are a number of islands located in this area, over which the existence of sovereignty is generally recognised. This concerns Bouvet Island, Heard and McDonald Islands, Crozet Islands, Kerguelen, Prince Edward Islands, South Georgia Islands and South Shetland Islands. ${ }^{24}$ At the time CCAMLR was being negotiated, France had established a 200-nautical mile zone for the Crozet Islands and Kerguelen. Article IV(2) of CCAMLR indicates that the French action in respect of these islands does not contradict its obligations under the Convention. A declaration of 19 May 1980 by the Chairman of the Conference at which CCAMLR was negotiated addressed the situation of the Crozet Islands and Kerguelen in more detail, including the recognition that France was entitled to establish a 200nautical mile zone. The understanding of the declaration also applies to other islands to the north of $60^{\circ} \mathrm{S}$ within the area of application of CCAMLR. ${ }^{25}$

In the negotiations of an Antarctic minerals regime the views of claimant states and non-claimant states with respect to jurisdiction over the sea-bed and its subsoil had to be reconciled. The compromise on this point is contained in Article 5 of the 1988 Convention on the Regulation of Antarctic Mineral Resource Activities ${ }^{26}$ (CRAMRA) on its area of application. ${ }^{27}$ Article 5, paragraphs 1 to 3, provides:

24 The sovereignty over these last two islands groups is in dispute between Argentina and the United Kingdom, but the existence of sovereignty over these islands is not rejected by third states, as is the case for territories covered by the Antarctic Treaty.

There were no objections to the declaration, which was incorporated in the Final Act of the Conference. On Art. IV(2) of CCAMLR and the declaration see further, e.g. E. Molenaar, "Southern Ocean Fisheries and the CCAMLR Regime" in A.G. Oude Elferink and D.R. Rothwell (eds.), note 9 above, pp. 293-315 at pp. 301-305; D.R. Rothwell, The Polar Regions and the Development of International Law (Cambridge, Cambridge University Press, 1996), pp. 124-128. Concluded on 2 June 1988, not yet entered into force ((1988) 27 International Legal Materials 868).

27 An agreement in principle on the area of application of the minerals regime had already been reached in 1981 at the eleventh Antarctic Treaty Consultative Meeting (ATCM). 
“1. This Convention shall, subject to paragraphs 2, 3 and 4 below, apply to the Antarctic Treaty area.

2. Without prejudice to the responsibilities of the Antarctic Treaty Consultative Parties under the Antarctic Treaty and measures pursuant to it, the Parties agree that this Convention shall regulate Antarctic mineral resource activities which take place on the continent of Antarctica and all Antarctic islands, including all ice shelves, south of 60 degrees south latitude and in the seabed and subsoil of adjacent offshore areas up to the deep seabed.

3. For the purposes of this Convention 'deep seabed' means the seabed and subsoil beyond the geographic extent of the continental shelf as the term continental shelf is defined in accordance with international law." 28

The Final Act of the Meeting at which CRAMRA was adopted contains two understandings on Article 5:

"The Meeting agreed that the area of regulation of Antarctic mineral resource activities defined in Article 5(2) of the Convention does not extend to any continental shelf appurtenant in accordance with international law to islands situated to the north of 60 south latitude.

The Meeting also agreed that the geographic extent of the continental shelf referred to in Article 5(3) of the Convention would be determined by reference to all the criteria and the rules embodied in paragraphs 1 to 7 of Article 76 of the United Nations Convention on the Law of the Sea." 29

The Final Act provides that it is without prejudice to the legal position of any party under the Antarctic Treaty. ${ }^{30}$

The definition of the area of application contained in CRAMRA indicates recognition of the existence of the Area and the fact that it would have been excluded from the regime for mineral exploitation established by CRAMRA. ${ }^{31}$ In defining the limit of the deep sea-bed reference is made to the continental shelf. On the one hand, the definition disconnects the continental shelf from the

contd.

Recommendation XI-1 provided that the regime should apply to all mineral resource activities on the Antarctic continent and its adjacent off-shore areas without encroachment on the deep sea-bed.

28 CRAMRA also contains an Article protecting the legal positions under the Antarctic Treaty, which uses similar wording to Art. IV of the Antarctic Treaty (CRAMRA, Art. 9).

29 Final Act of the Fourth Special Antarctic Treaty Consultative Meeting on Antarctic Mineral Resources of 2 June 1988 (reproduced in R. Wolfrum, The Convention on the Regulation of Antarctic Mineral Resource Activities; An Attempt to Break New Ground (Berlin, SpringerVerlag, 1991), p. 97, at p. 99.

Ibid., p. 100

The following interpretation of Art. 5 of CRAMRA to a large extent draws on A. Watts, International Law and the Antarctic Treaty System (Cambridge, Grotius Publications Limited, 1992), p. 154. 
existence of a coastal state by reference to the "geographic extent of the continental shelf". This is also accomplished by defining the area of application in Article 5(1) negatively, by reference to its extension up to the deep sea-bed. The avoidance of any express reference to coastal states further safeguards the interest of the non-claimant states. At the same time, reference is made to the continental shelf as defined in international law. The Final Act further specifies that the relevant rules of international law are contained in Article 76, paragraphs 1 to 7 of the LOS Convention. The reference to Article 76 assures that if a claimant state were to decide to define the outer limit of its continental shelf more precisely, this would not lead to a discrepancy with the limit of offshore areas defined in Article 5(1) of CRAMRA. ${ }^{32}$

Although Article 5 did much to arrive at a workable solution of the area of application of CRAMRA, its implementation would not have been without difficulty. This would have required agreement on the procedure to establish the extent of the continental shelf (either the procedure contained in Article 76 of the LOS Convention or a procedure particularly designed for the situation in Antarctica) and the location of the baseline along the Antarctic continent. ${ }^{33}$ The definition of the area of application of CRAMRA indicated that dealing with Article 76 of the LOS Convention (or at least its first seven paragraphs) in the abstract did not pose insurmountable difficulties to the ATS.

The opposition to mining activities in Antarctica that developed after the adoption of CRAMRA led to the negotiation of the Madrid Protocol, ${ }^{34}$ which contains a prohibition on mineral resource activities and sets aside the minerals regime contained in CRAMRA. The Protocol, which is supplemental to the Antarctic Treaty and neither modifies nor amends it, ${ }^{35}$ applies to the Antarctic Treaty area. Unlike CRAMRA, the Protocol does not make a reference to either the deep sea-bed or the continental shelf. Consequently, for the moment there is no further need to define the continental shelf more precisely within the framework of the ATS, ${ }^{36}$ as might have been required after entry into force of CRAMRA. ${ }^{37}$

At the time CRAMRA was being negotiated none of the claimant states was a party to the LOS Convention. However, it is likely that at that time Art. 76 reflected customary international law or at least had become a reference point for states wishing to establish the outer limit of their continental shelf beyond 200 nautical miles (see A.G. Oude Elferink, "The Outer Continental Shelf in the Arctic: Application of Article 76 of the LOS Convention in a Regional Context" in A.G. Oude Elferink and D.R. Rothwell (eds.), note 9 above, pp. 139-156, at pp. 142-143).

Cf. D. Vidas, "The Southern Ocean Seabed: Arena for Conflicting Regimes?" in D. Vidas and W. Ostreng (eds.), Order for the Oceans at the Turn of the Century (The Hague, Kluwer Law International, 1999), pp. 291-314, at p. 297.

34 Protocol on Environmental Protection to the Antarctic Treaty; concluded on 21 June 1991, entered into force on 15 January 1998 ((1991) 30 ILM 1455). Madrid Protocol, Art. 4(1).

36 See also D. Vidas, note 33 above, p. 298.

37 The Madrid Protocol applies to all maritime areas south of $60^{\circ} \mathrm{S}$, including areas beyond the outer limit of the continental shelf defined in conformity with Art. 76 of the LOS Convention. 
Antarctic claimant states have adopted legislation concerning most maritime zones for their Antarctic territories. ${ }^{38}$ National legislation concerning maritime zones has taken a number of approaches. In some cases, legislation is applicable to all the territory of a claimant state, without explicitly referring to Antarctic or other territories. In other cases, legislation makes explicit reference to the Antarctic territory of a state or islands to the north of $60^{\circ} \mathrm{S}$. In general, this legislation defines the extent and outer limit of maritime zones by reference to the general rules of the law of the sea applicable to this matter. Claimant states have from time to time explicitly provided for limitations on the applicability of legislation within such zones. For instance, the United Kingdom established a 200-nautical mile zone for South Georgia and the South Sandwich Islands in 1993. ${ }^{39}$ This zone extends south of $60^{\circ} \mathrm{S}$, but fishing legislation does not apply to this part of the zone. ${ }^{40}$

The definition of the baseline of Antarctic territories is a matter that has not been addressed explicitly in national legislation. ${ }^{41}$ On the other hand, states have expressly addressed the definition of the baseline around islands to the north of $60^{\circ} \mathrm{S} .42$

Non-claimant states have reacted to such legislation or in other instances by confirming their position on the status of the waters of Antarctica. For example, one United States government official has stated that:

"In the area covered by the Antarctic Treaty, the United States, of course, with the possible exception of a couple of islands, clearly does not recognize sovereignty. Thus, we do not recognize the claims of sovereignty or maritime jurisdiction south of 60 degrees latitude." 43

contd.

This raises the question of whether the regime of the Protocol is compatible with the regime contained in Part XI of the LOS Convention (see further D. Vidas, note 33 above, pp. 291-314; and D. Vidas, "Emerging Law of the Sea Issues in the Antarctic Maritime Area: A Heritage for the New Century?", (2000) 31 Ocean Development and International Law, 197-222 at 209-216; see also A. Van der Essen, note 10 above, pp. 559-560).

38 For a more extensive discussion of this practice, see e.g. P. Vigni, note 9 above

39 South Georgia and South Sandwich Islands; Proclamation (Maritime Zone) No. 1 of 7 May 1993 ((1993) Law of the Sea Bulletin 24, 47).

40 E. Molenaar, "CCAMLR and Southern Ocean Fisheries", (2001) 16 International Journal of Marine and Coastal Law, 465-499 at 478; see also the examples given in P. Vigni, note 9 above, p. 88.

41 See further D.R. Rothwell, "Antarctic Baselines: Flexing the Law for Ice-Covered Coastlines" in A.G. Oude Elferink and D.R. Rothwell (eds.), note 9 above, pp. 49-68, at pp. 59-61. The issue of the baseline in Antarctica was addressed in a report in 1926 of a British Imperial Conference Committee, which recognised that the territorial sea could be measured from ice barriers which are a permanent extension of the land proper (see ibid., p. 61).

42 For instance, the United Kingdom defined a number of straight baselines for the South Georgia and South Sandwich Islands in 1989 (Schedule to the South Atlantic Territories; The South Georgia and South Sandwich Islands (Territorial Sea) Order 1989 (1989 No. 1995) of 1 November 1989).

43 Statement by R. Tucker Scully in the United States Senate, Antarctic Living Marine Resources Negotiations, Hearing of June 14, 1978, at 7 (as reproduced in F. Orrego Vicuña, note 4 above, p. 109); see also the examples given in S.B. Kaye, note 9 above, p. 127; T. Scovazzi, note 9 above, pp. $380-383$. 
The United States considers that the waters surrounding the territories included in the Antarctic Treaty area are high seas.

National legislation in respect of maritime zones points to a number of conclusions. Claimant states have not refrained from asserting the existence of maritime zones in the Antarctic Treaty area because of the existence of the Treaty. At the same time, not all states have pursued this matter equally. For instance, some states, which have established an EEZ for their metropolitan territory, have refrained from doing so for their Antarctic territory or have taken this step at a later date. The differences between national approaches suggest that claimant states may also diverge in the way they will deal with their obligations under Article 76 of the LOS Convention in respect of the outer limit of the continental shelf. Certain actions may be perceived by one state as safeguarding its legal position in respect of its Antarctic claim, but by another as falling short of what is required in this respect. These different views will have to be reconciled in any common approach that the claimant states and other states involved may try to develop. The experience with the definition of the continental shelf in the framework of CRAMRA and of maritime zones in the framework of other ATS instruments indicates that in general a formulation has been found that satisfies both claimant and non-claimant states. National legislation shows, similarly to the negotiations on various ATS instruments, that maritime zones of the islands to the north of $60^{\circ} \mathrm{S}$ are treated differently from maritime zones of territories within the Antarctic Treaty area.

\section{The Establishment of the Outer Limit of the Continental Shelf beyond 200 Nautical Miles under the LOS Convention ${ }^{44}$}

Article 76 of the LOS Convention defines the continental shelf by two basic criteria. The continental shelf of the coastal state extends either to the outer edge of the continental margin or to 200 nautical miles from the baseline from which the breadth of the territorial sea is measured where the outer edge of the continental shelf does not extend up to that distance. In the former case, paragraphs 4 to 7 of

44 The view has been expressed that as the third United Nations Conference on the Law of the Sea did not deal with the status of Antarctica, the LOS Convention is not applicable to Antarctica (see the references in D.R. Rothwell and C.C. Joyner, "The Polar Oceans and the Law of the Sea" in A.G. Oude Elferink and D.R. Rothwell (eds.), note 9 above, pp. 1-22, at p. 13, n. 65). This view is in any case not shared by the claimant states, which have to decide on how to deal with the continental shelf of their Antarctic territories in preparing a submission to the CLCS. A 1986 Report of the Secretary-General of the United Nations found that:

"One of the main objectives of the [LOS] Convention is to establish a new legal order for the seas and the oceans, taking into account recent developments and the needs of the international community. It is a global convention applicable to all ocean space. No area of ocean space is excluded. It follows that the Convention must be of significance to the Southern Ocean in the sense that its provisions also apply to that ocean." (Question of Antarctica, Report of the Secretary-General, A/41/722 of 17 November 1986, para. 115; see also D.R. Rothwell and C.C. Joyner, as above, p. 13; F. Orrego Vicuña, note 4 above, pp. 101-102.) 
Article 76 provide a number of criteria to establish the outer limit of the continental shelf. ${ }^{45}$ These provisions are more complex than most other rules on the establishment of the outer limit of maritime zones. However, coastal states can deal with all of these rules in a similar way. Just as a state can define an EEZ without indicating the location of the 200-nautical mile limit, it can limit itself to providing that certain provisions of Article 76 are relevant for the definition of the outer limit of its continental shelf. This indicates that the substantive provisions of Article 76 no more pose a threat to the stability of the ATS than any other rule on the extent of maritime zones. In fact, the substantive provisions contained in Article 76 have been used to define the geographical scope of the minerals regime of CRAMRA. ${ }^{46}$ Another example in this respect is a statement of the New Zealand government that "the outer limits of the minerals regime in respect of the Ross Dependency will not extend beyond the limits prescribed in article 76 of the 1982 United Nations Convention on the Law of the Sea". 47

What sets Article 76 apart from other provisions on the outer limit of maritime zones is that it gives an international body, the CLCS, a role in establishing this limit. ${ }^{48}$ In case the continental shelf of a state extends beyond 200 nautical miles from the relevant baseline, it is required to submit information on the outer limit to the CLCS. The Commission is to make recommendations to the coastal state and the limits established by that state on the basis of these recommendations shall be final and binding.

Annex II to the LOS Convention provides that a state has to make its submission "as soon as possible but in any case within 10 years of the entry into force of this Convention for that state". 49 This is an obligation resting on states parties, which they have to fulfill in good faith. ${ }^{50}$ If a coastal state intends to establish the outer limit of its continental shelf beyond 200 nautical miles in conformity with Article 76 of the LOS Convention, it will have to respect the 10 year time limit. A state that has a claim to territory in the Antarctic Treaty area

45 For a detailed discussion of Art. 76 of the LOS Convention, see e.g. S.N. Nandan and S. Rosenne, United Nations Convention on the Law of the Sea 1982; A Commentary (Dordrecht, Martinus Nijhoff Publishers, 1993), pp. 837-883; and The Law of the Sea; Definition of the Continental Shelf; An Examination of the Relevant Provisions of the United Nations Convention on the Law of the Sea (New York, United Nations, 1993).

46 See further, text at note 29 above.

47 A/39/583 (Part II), Vol. III of 9 November 1984, p. 20 (reproduced in F. Orrego Vicuña, note 4 above, p. 126, n. 80 ).

48 The rules governing the establishment and operation of the Commission are contained in Annex II to the Convention. The Commission started its work in 1997, after the first election of its members by the Meeting of States Parties to the Convention. The Commission has adopted Rules of Procedure (note 7 above) and Scientific and Technical Guidelines (CLCS/11 of 13 May 1999; CLCS/11/Add.1 of 3 September 1999; CLCS/11/Corr.1 of 24 February 2000). The Guidelines aim to clarify the scope and depth of admissible scientific and technical evidence to be examined by the Commission during its consideration of submissions (Scientific and Technical Guidelines, para.

1.2). The first submission to the CLCS was made by the Russian Federation in December 2001.

49 LOS Convention, Annex II, Art. 4.

so LOS Convention, Art. 300 . Art. 300 reflects the fundamental rule of pacta sunt servanda. 
will have to consider how to deal with the outer limit of the continental shelf of such areas in relation to the 10 -year time limit.

The implications of the provision concerning the time limit for making submissions are not completely clear. ${ }^{51}$ Article 4 of Annex II does not spell out any consequences of non-compliance. The Article would seem to imply that after the 10-year time limit has expired, a coastal state is no longer entitled to make a submission to the CLCS concerning the outer limit of its continental shelf beyond 200 nautical miles. Alternatively, the CLCS would not be under an obligation to entertain a submission that is made after the 10-year time limit has expired.

Non-compliance with this provision does not seem to have consequences for the entitlement of the coastal state to this part of its continental shelf. ${ }^{52}$ This is confirmed by Article 76 of the LOS Convention. Its paragraph 1 lays down that continental shelf entitlement is based on distance from the coast or natural prolongation. The rules for establishing the limits of the continental shelf in the latter case are contained in paragraphs 4 to 6 of Article $76 .^{53}$ The CLCS is concerned with the establishment of the outer limits of the continental shelf and is not competent to rule on the existence of a valid title to the continental shelf. ${ }^{54}$ The fact that the procedure for establishing the outer limits of the continental shelf is not constitutive of entitlement is confirmed by Article 77(3) of the LOS Convention, which provides that the rights of the coastal state over the shelf do not depend on occupation or any express proclamation..$^{55}$ The exercise of rights by coastal states over their continental shelf beyond 200 nautical miles, for which in no case outer limits have been established in conformity with Article 76 of the LOS Convention, confirms the view that this procedure is not constitutive of entitlement. ${ }^{56}$

Although the absence of outer limits established in conformity with the procedure under Article 76 of the LOS Convention does not have consequences

See also Press Releases SEA/1704 of 16 May 2001 and SEA/1706 of 17 May 2001, both reporting on the eleventh Meeting of States Parties to the LOS Convention.

52 See also SPLOS/64 of 1 May 2001 , p. 12, para. 45.

53 LOS Convention, Art. 76(2). The same distinction between entitlement and delimitation is made in the case of land territory and in the delimitation of maritime zones between neighbouring states. At the same time, both questions are closely related (see further R.Y. Jennings and A. Watts (eds), Oppenheim's International Law (London, Longman, 9th ed., 1992), pp. 668-669; I. Brownlie,

Principles of Public International Law (Oxford, Oxford University Press, 4th ed., 1990), pp. 124-125).

The CLCS will have to satisfy itself that there actually exists an entitlement to a continental shelf beyond 200 nautical miles in case a coastal state submits information concerning the outer limits of its continental shelf, because application of the rules concerning the outer limit of the continental shelf requires such entitlement (see LOS Convention, Art. 76, especially para. 4; see also Scientific and Technical Guidelines, note 48 above, para. 2.2).

55 See also SPLOS/73 of 14 June, p. 12, para. 75.

56 See however, the Fact Sheet "Australia, Antarctica and the Law of the Sea: Defining the Limits of the Continental Shelf" (prepared by the Antarctic Treaty and Government Section, Australian Antarctic Division - December 1999), p. 1, which states that "Australia must submit data before [the time limit established by Art. 4 of Annex II to the LOS Convention] if it wishes to exercise its rights under Article 77 of that Convention". The Fact Sheet later varies this view, pointing out that if Australia does not submit data "it is possible that it would forego the rights made available by the [LOS Convention]" (ibid., p. 4). 
for entitlement to the continental shelf as such, certain negative implications are possible. As was noted above, the submission of information within the 10-year time limit is an obligation resting on states parties to the Convention. If a state does not comply with this provision it may no longer be in a position to establish the outer limit of its continental shelf beyond 200 nautical miles in conformity with Article 76 of the Convention. The absence of such an outer limit is bound to raise doubts over the exact extent of this part of a state's continental shelf, with the attendant difficulties for the coastal state in enjoying these rights it has over this shelf area. ${ }^{57}$

The 10-year time limit has been relaxed by a decision of the Meeting of States Parties to the LOS Convention of 29 May 2001. Since 1994, there had been a gradual realisation of the problems faced by especially developing states in complying with the 10-year time limit. ${ }^{58}$ To address this issue, the May 2001 decision provides that for states parties for which the Convention entered into force before 13 May 1999, the 10-year time period referred to in Article 4 of Annex II to the Convention shall be taken to have commenced on that date. ${ }^{59} \mathrm{It}$ was furthermore decided to keep the general ability of states to fulfill the requirements of Article 4 of Annex II under review. ${ }^{60}$

In the discussion of the deferral of the 10 -year time limit no reference was made to possible implications of the Antarctic Treaty for the implementation of Article 76 of the LOS Convention. A background paper prepared by the United Nations Secretariat did make reference to technical difficulties that may lead to a partial submission. Reference was made to uncertainties resulting from the geophysical structure of the continent (e.g. ice-covered areas), extreme weather conditions and the absence of available affordable technical assistance in areas which are very difficult to access. ${ }^{61}$ Some states parties were of the view that a state which for technical reasons was only able to make a partial submission within the 10 -year time limit should be viewed as having complied with Article 4 of Annex II to the LOS Convention. ${ }^{62}$

See also SPLOS/64 of 1 May 2001, p. 12, paras. 44-47.

See e.g. SPLOS/72 of 29 May 2001, Preamble.

Ibid., para. (a). On this date the CLCS had adopted its Scientific and Technical Guidelines. Among the various dates which had been suggested, this was the date which gave states most additional time (see e.g. SPLOS/64 of 1 May 2001, paras. 29-32). Some doubts have been voiced concerning the validity of this decision of the Meeting of States Parties, which is not among the procedures for amendment of the Convention envisaged in its Arts. 312 and 313. However, this does not exclude the amendment of the Convention by other means. The Meeting of States Parties on two earlier occasions decided on a change in procedural rules contained in the LOS Convention. This concerned a postponement of the date of election of the members of the International Tribunal for the Law of the Sea and the CLCS provided for in the Convention (see LOS Convention, Annex II, Art. 2(2) and Annex VI, Art. 4(3); SPLOS/3 of 28 February 1995, para. 16; SPLOS/5 of 22 February 1996, para. 20).

SPLOS/72 of 29 May 2001, para. (b).

SPLOS/64 of 1 May 2001, p. 14, para. 56.

SPLOS/73 of 14 June 2001 , p. 12, para. 77. 
Viewed from the perspective of the ATS, a submission of a claimant state in respect of its Antarctic territories would be in stark contrast with "constructive ambiguity". Under Article 76 of the LOS Convention a coastal state has to make a submission to the CLCS. The outer limits established by the coastal state on the basis of the recommendations of the CLCS shall be final and binding. ${ }^{63}$ The process of establishing outer limits under Article 76 of the LOS Convention, if completed, would provide an unprecedented recognition of the existence of coastal state jurisdiction in the Antarctic Treaty area. ${ }^{64}$

Article 76 of and Annex II to the LOS Convention do not provide for any exceptions to the rules concerning submissions. ${ }^{65}$ However, Article 311(2) of the Convention may provide states with a ground for not complying with the 10-year time limit contained in Annex II to the Convention. Article 311(2) reads:

"This Convention shall not alter the rights and obligations of States Parties which arise from other agreements compatible with this Convention and which do not affect the enjoyment by other States Parties of their rights or the performance of their obligations under this Convention."

If all the criteria of Article 311(2) would be met, it would offer a possibility to defer a submission on the Antarctic continental shelf. ${ }^{66}$

Unlike the LOS Convention, the Rules of Procedure of the CLCS explicitly recognise that there may be situations in which a submission by a coastal state may be complicated by special circumstances. The general rule in this respect is contained in Rule 45 of the Rules of Procedure and a detailed regulation is provided in Annex I to the Rules of Procedure. This Annex is applicable to submissions in case of a dispute between states with opposite or adjacent coasts or in other cases of unresolved land or maritime disputes ${ }^{67}$ The Annex starts out

LOS Convention, Art. 76(8). It is not altogether clear whether the limit ipso facto becomes final and binding on the coastal state or erga omnes.

64 See also infra on the problems surrounding the definition of baselines along the Antarctic continent.

65 A basis for an exception is contained in Art. 9 of Annex II which provides that " $[\mathrm{t}]$ he actions of the Commission shall not prejudice matters relating to the delimitation of boundaries between States with opposite or adjacent coasts". This provision can be used to justify a special approach in respect of submissions involving overlapping areas of continental shelf (see further note below). See further, text at note 98 below and following. On Art. 311(2) of the LOS Convention see further B. Kwiatkowska, "The Australia and New Zealand v Japan Southern Bluefin Tuna (Jurisdiction and Admissibility) Award of the First Law of the Sea Convention Annex VII Arbitral Tribunal", (2001) 16 International Journal for Marine and Coastal Law, 239-293, at 261, n. 95 .

67 A first draft of Rule 45 only concerned disputes on the delimitation of the continental shelf between opposite and adjacent states. A coastal state making a submission was required to inform the Commission of such disputes (Draft Rules of Procedure of the Commission on the Limits of the Continental Shelf, Rule 44 (SPLOS/CLCS/WP.1 of 26 July 1996)). The basis for Rule 45 of and Annex I to the Rules of Procedure is in part provided by Art. 9 of Annex II to the LOS Convention, which deals with the issue of boundaries between states with opposite or adjacent coasts (see also G. French, "The Antarctic Treaty and Dispute Resolution", paper 
by recognising that the competence with respect to such disputes rests with states. The initiative to identify the existence of a dispute rests with the coastal state, which, in making a submission, shall inform the CLCS of such disputes. ${ }^{68}$ The coastal state does not have to inform the Commission of all land or maritime disputes in respect of a territory generating the continental shelf. As Annex I to the Rules of Procedure of the CLCS indicates, it is concerned with "unresolved land and maritime disputes, in relation to the submission". 69

Annex I does not provide a definition of the term "dispute". This definition has been considered on a number of occasions by the International Court of Justice (ICJ). In the East Timor case the Court recalled that

"in the sense accepted in its jurisprudence and that of its predecessor, a dispute is a disagreement on a point of law or fact, a conflict of legal views or interests between parties [...]. In order to establish the existence of a dispute, '[I]t must be shown that the claim of one party is positively opposed by the other'." 70

The Chairman of the CLCS has indicated that Annex I "dealt with the complex issue of how the Commission should treat possible submissions containing areas under actual or potential delimitation dispute". 71 This suggests that the CLCS will adopt a low threshold for establishing the presence of disputes under Annex I. At least in one instance Annex I to the Rules of Procedure of the Commission does not require the existence of a dispute to be applicable. Paragraph 3 allows for a partial submission "in order not to prejudice questions relating to the delimitation of the continental shelf between States in any other portion or portions of the continental shelf for which a submission may be made later". Similarly, Article 9 of Annex II to the LOS Convention also does not refer to disputes, but only to matters relating to the delimitation of boundaries.

contd.

presented at the Southern Ocean Law of the Sea and Maritime Disputes Workshop, Faculty of Law, University of Sydney, Australia, 19 October 2001). The Convention does not provide an explicit basis to adopt a special procedure for other maritime or territorial disputes. The competence to deal with this issue can be considered to be implied in the competence of the CLCS under the LOS Convention. Recommendations of the CLCS in cases in which maritime or territorial disputes exist, without agreement of all the parties to such disputes, would question the legality and threaten the effectiveness of the procedure involving the CLCS. Annex I was adopted by the CLCS after consideration by the Meeting of States Parties to the LOS Convention.

Rules of Procedure, Annex I, para. 2. Moreover, the state concerned shall ensure the CLCS to the extent possible that the submission will not prejudice matters relating to the delimitation of boundaries between states (ibid.).

69 Ibid., (emphasis provided). Cf. CLCS/31 of 5 April 2002, p. 6 for the comment of the Russian Federation on the territorial dispute with Japan in the Sea of Okhotsk.

70 Case concerning East Timor (Portugal v Australia), Judgment of 30 June 1995; [1995] Reports of Judgments, Advisory Opinions and Orders; The International Court of Justice (ICJ Rep), 99-100, para. 22.

71 CLCS/7 of 15 May 1998, para. 5 (emphasis provided). 
If a coastal state considers that no land or maritime dispute exists in relation to the submission, it is possible for other states, which have a different view in this respect, to indicate this. ${ }^{72}$ In this case, it will have to be decided if a dispute in the sense of Annex I to the Rules of Procedure of the CLCS exists. The Annex does not indicate how the CLCS will proceed in case states differ over the question if a dispute in relation to a submission exists.

The ICJ and other tribunals have held that they are competent to decide the real dispute submitted to them, which does not have to coincide with the characterisation given by the parties..$^{73}$ It not likely that the CLCS, which is not a court of law, and whose task it is to make recommendations concerning the outer limits of the continental shelf and not to settle disputes related to these limits, can or will adopt a similar approach. Annex I to the Rules of Procedure recognises that the competence with respect to such disputes rests with states. This suggests that the CLCS will not characterise what is the real dispute between the states involved. At the same time, the rules adopted by the CLCS indicate that it will make an independent evaluation of the existence of a dispute. ${ }^{74}$

If a dispute exists in relation to a submission, a number of approaches are possible, depending on the nature of the dispute and the views of the states involved on how to deal with the submission..$^{75}$ Paragraph 5 of Annex $I$ to the Rules of Procedure, which is applicable to all land and maritime disputes, provides that the Commission may examine one or more submissions in the areas

Rule 49 of the Rules of Procedure of the CLCS provides that the Secretary-General of the United Nations shall notify all members of the United Nations, including states parties to the LOS Convention, of the receipt of a submission and shall make public the proposed outer limits of the continental shelf pursuant to the submission.

See e.g. Fisheries Jurisdiction case (Spain v Canada); Judgment of 4 December 1998 (Jurisdiction of the Court); [1998] ICJ Rep, para. 31. For a detailed discussion of this issue see A. Kanehara, "Determination of the Dispute in the Southern Bluefin Tuna Case", (2002) 60 Rikkyo Hogaku (St. Paul's Review of Law and Politics), 1-54, at 2-19.

74 An earlier draft of Annex $I$ to the Rules of Procedure contained a paragraph allowing the Commission, as appropriate, to ascertain whether there may exist any dispute in relation to a submission (CLCS/3 of 12 September 1997, p. 20, para. 5). This text was not included in a revised version of Annex I (CLCS/3/Rev.1 of 14 May 1998, p. 20). The Internal procedure of the subcommission of CLCS charges the subcommission dealing with a submission to examine the information on disputes presented by the coastal state, or on any dispute relevant to the submission. If necessary, the subcommission shall take action based on the procedures contained in Annex I to the Rules of Procedure of the Commission (CLCS/L.12 of 25 May 2001, para. 8). The CLCS will have to deal with this issue in connection with the submission of the Russian Federation. A number of states submitted observations on the information on the outer limits contained in the submission that had been circulated by the Secretary-General of the United Nations. A statement in connection with the presentation of the submission by the Russian Federation suggests that these observations do not point to the existence of disputes of relevance for the consideration of the Russian submission (see CLCS/31 of 5 April 2002, p. 6). For some of the observations this seems indeed to be the case, but for others this may be questionable.

States can also opt to resolve a territorial or maritime dispute before proceeding with a submission to the CLCS. This can hardly be considered to be a viable option for submissions involving the continental shelf in Antarctica. 
under dispute with the prior consent of all the states that are parties to the dispute. If a state makes a partial submission, in conformity with paragraph 3 , a submission for the areas not included in the initial submission may be made after the 10-year time limit specified in Article 4 of Annex II of the LOS Convention. ${ }^{76}$ States may, by agreement, also make separate or joint submission in cases involving continental shelf boundaries. ${ }^{77}$

\section{The Political and Physical Geography of Antarctica: Consequences for Submissions under Article 76 of the LOS Convention}

Seven states have claims over parts of the Antarctic continent and its adjacent islands south of $60^{\circ} \mathrm{S} .{ }^{78}$ The largest area in Antarctica, about 40 per cent of the continent, is claimed by Australia. The Australian Antarctic Territory (AAT) consists of two separate sectors. The larger of these sectors has a coastal front of several thousand kilometres. To the west it is bounded by the Norwegian Antarctic territory and to the east by the French Adelie Land, which is wedged in between the two parts of the AAT. The other part of the AAT is bounded by the New Zealand sector on the east. Argentina, Chile and the United Kingdom have partially overlapping claims to the part of the Antarctic continent to the south of Latin America. The sector of the Antarctic continent between the Chilean and New Zealand claims has remained unclaimed. Only the island of Peter I, offshore of this sector, has been claimed by Norway.

Provisional information suggests that under Article 76 of the LOS Convention most of the continental shelf of the Antarctic continent may extend beyond 200 nautical miles from the baseline. ${ }^{79}$ This indicates that all claimant states will have to consider how to deal with the requirement of Article 76 to submit information on this continental shelf to the CLCS.

The continental shelf of a number of islands, which themselves are situated outside the Antarctic Treaty area, such as Heard and McDonald (Australia), Macquarie (Australia) and the South Sandwich Islands (in dispute between the United Kingdom and Argentina), may extend into the Antarctic Treaty area. The entitlement to a continental shelf of these islands is not disputed, ${ }^{80}$ but a submission in respect of these islands will have to deal with the implications of a continental shelf extending into the Antarctic Treaty area. This will be particularly the case if the continental shelf of one of these islands will overlap with the continental shelf of Antarctic territories.

Three categories of land and maritime disputes in the sense of Annex I to the

Under para. 5 of the Annex this issue does not arise as the states concerned will have made a submission.

Rules of Procedure of the CLCS, Annex I, para. 4.

For further information on these claims, see e.g. D.R. Rothwell, note 25 above, pp. 54-58.

For further information on the continental shelf of Antarctica see C.C. Joyner, Antarctica and the Law of the Sea (Dordrecht, Martinus Nijhoff Publishers, 1992), pp. 108-113.

See supra; see also S.B. Kaye, note 10 above, pp. 136-137. 

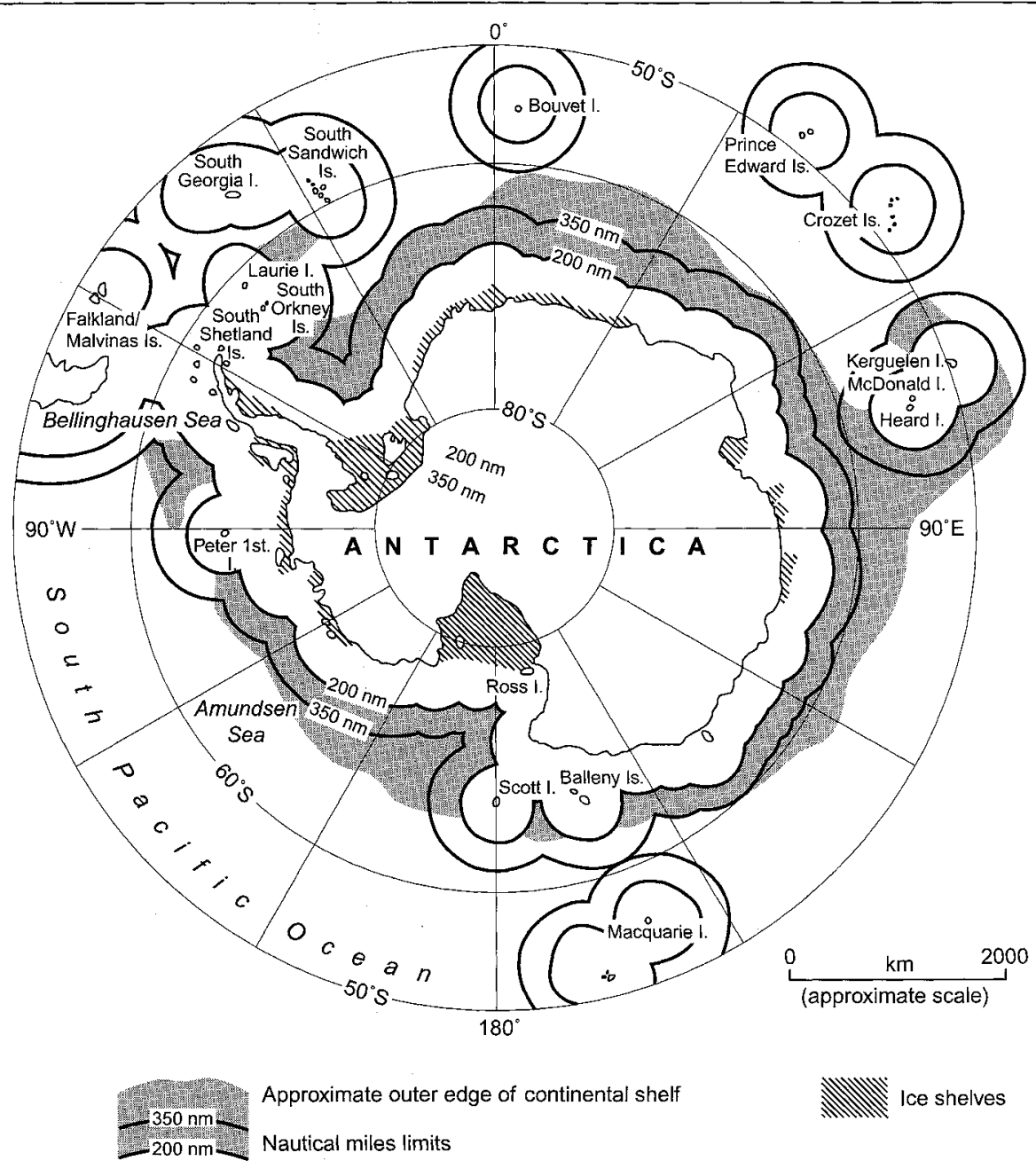

Approximate outer edge of continental shelf

Ice shelves

Nautical miles limits

Information on the outer edge of the continental margin is not included for some sub-Antarctic islands and the Falkland/Malvinas Islands

Figure 2 The Continental Shelf in Antarctica

(C) Kluwer Law International, 2002 
Rules of Procedure of the CLCS can be identified in respect of territory south of $60^{\circ} \mathrm{S}$. First of all, this concerns the question whether there are coastal states and the attendant maritime zones in Antarctica. ${ }^{81}$ Antarctic claimant states will answer these questions positively, but other states have rejected the existence of coastal states and coastal state jurisdiction. Another category of disputes in the sense of Annex I to the Rules of Procedure of the CLCS is the overlap of claims to Antarctic territory between Argentina, Chile and the United Kingdom. Finally, the continental shelf of the various claimant states overlaps. The continental shelf of the island of Peter I and the Chilean and New Zealand sectors also overlaps with the continental shelf of the unclaimed sector. ${ }^{82}$

The first category of disputes touches upon the fundamental underpinnings of the ATS and the status of Antarctica under general international law. An uncontested submission by a claimant state would weaken the position of nonclaimant states inside and outside the ATS concerning the legal states of Antarctica and its maritime space.

The overlapping claims to Antarctic territory between Argentina, Chile and the United Kingdom and the overlapping areas of continental shelf can be considered as secondary issues in comparison to the first category of disputes in one respect. If a state makes observations in respect of a submission concerning the existence of the Antarctic Treaty and diverging views over the existence of coastal states which indicate the existence of a dispute in the sense of Annex $I$, all states concerned have to agree to the consideration of the submission by the CLCS. Whether the states directly involved in the two other types of issues have reached an agreement on how to deal with those issues under Annex I then becomes irrelevant.

On the other hand, the overlapping claims to Antarctic territory between Argentina, Chile and the United Kingdom and the overlap of areas of continental shelf might be used by states if they want to defer a submission in respect of their Antarctic continental shelf. A submission by Argentina, Chile or the United Kingdom could certainly be said to prejudice questions related to the delimitation of their continental shelf boundaries. The same can be said of overlapping continental shelf areas of other claimant states. France, and Australia, in relation to the part of the AAT between the French and New Zealand claims, would clearly

See also S.B. Kaye, note 10 above, pp. 127-128; A. Zinchenko, The Global Vision of the Law of the Sea System, and its Relation with the Commission on the Limits of the Continental Shelf (paper presented at the Continental Shelf Workshop, Buenos Aires, Argentina, 13-17 November 2000), pp. 40-41.

This case would seem to be similar to the case in which there are two states with opposite or adjacent coasts whose continental shelf overlaps. Chile, New Zealand and Norway will have to take into account the potential maritime zones of the unclaimed sector, in view of their obligations under Art. IV of the Antarctic Treaty (cf. S.A. Hajost, "Authority to Manage Fisheries and Mineral Resources of the Southern Ocean: The Perspective of Non-Claimant Parties to the Antarctic Treaty" in T.A. Clingan Jr. (ed.), The Law of the Sea: What Lies Ahead? (Honolulu, The Law of the Sea Institute, University of Hawaii, 1988), pp. 369-379, at p. 376; see also S.B. Kaye, note 10 above, pp. 132-133). 
have the possibility to exclude these areas completely from their submission to the CLCS. All of the continental shelf of these territories can without difficulty be argued to be of relevance for the delimitation of the continental shelf between opposite or adjacent states. Application of this same provision to the entire continental shelf of most other territories in Antarctica would require a more extensive interpretation. The broad formulation "questions relating to the delimitation of boundaries" of paragraph 3 of Annex I of the Rules of Procedure would seem to leave room for this.

\section{The Actions and Options of the Antarctic Claimant States and Other States}

All Antarctic claimant states have become a party to the LOS Convention and will have to meet the 10-year time limit for making a submission to the CLCS. The date on which the claimant states ratified or acceded to the Convention is (in chronological order): 5 October 1994 (Australia); 1 December 1995 (Argentina); 11 April 1996 (France); 24 June 1996 (Norway); 19 July 1996 (New Zealand); 25 July 1997 (United Kingdom); and 25 August 1997 (Chile). This implied that Australia would have had to make its submission by 16 November $2004,{ }^{83}$ to be followed by the other claimant states between 2005 and 2007 .

The deferral of the 10-year time limit by the Meeting of States Parties to the LOS Convention until $2009^{84}$ gives Antarctic claimant states (and other interested states) an additional five years to consider how to deal with the application of Article 76 of the LOS Convention in the context of the ATS. At the same time, some states may consider it appropriate to make a submission to the Commission well before the 10-year time limit expires for them. ${ }^{85} \mathrm{~A}$ state may choose to submit information for various areas at different times.

Antarctic claimant states appear to have been considering for some time how to deal with the continental shelf of their Antarctic territories in connection with a submission to the CLCS. Australia took a decision to take action to define the outer limits of the continental shelf beyond 200 nautical miles of the AAT on 2 December $1999 .{ }^{86}$ Apparently, this decision was only taken after it had become clear that the CLCS would not accept a proposal made in 1998 that the deadline for lodging submissions in respect of the continental shelf in Antarctica be deferred. ${ }^{87}$ Reportedly, Australia had also sought other ways of working with

87 Fact Sheet, note 56 above, p. 4 . There is no reference to such a proposal in any document issued by the CLCS.

For the provisions on entry into force of the LOS Convention, see its Art. 308.

See further, text at notes 58 to 60 above.

This is illustrated by the submission of the Russian Federation to the CLCS on 20 December 2001, whereas the Russian Federation had ratified the LOS Convention on 12 March 1997.

Fact Sheet, note 56 above, p. 1. For a discussion of the Australian case see also J. Green, "Australian Maritime Boundaries: The Australian Antarctic Territory", (2001) 25 Marine Policy, 1- 
parties to the LOS Convention and claimant states and other parties to the Antarctic Treaty to find an acceptable solution to this problem. Australia has indicated its commitment to continue working with other claimant states and other Antarctic Treaty parties "to ensure that Australia's interests and the interests of the Treaty as a whole are respected". 88 At least in 1999 Australia had not yet taken the decision on the propriety of making a submission for the AAT, but considered it necessary to start the collection of data on the continental shelf of the AAT to keep all its options open. An important consideration in reaching a decision in respect of a submission for the AAT will be the fact that

"with respect to Antarctica, Australia has consistently acted in accordance with its position as a State claiming territorial sovereignty. Failure to take action on this occasion could be seen as a limitation on Australia's commitment to the AAT, a commitment which should not be doubted". 89

As far as can be established, other claimant states so far have not actively pursued the preparation of information for an eventual submission on their Antarctic continental shelf to the CLCS. ${ }^{90}$ Like Australia, the other claimant states also have other territories that have a continental shelf beyond 200 nautical miles. For these continental shelf areas, these states have been preparing a submission to the CLCS for a number of years.

The issue of the Antarctic continental shelf in relation to submissions to the CLCS seems to have been discussed between the claimant states, and also with the United States and the Russian Federation on a number of occasions. Thus far a common position does not seem to have emerged.

A number of solutions have been suggested to deal with the continental shelf in Antarctica. These concern both the procedures to be employed and definitions to be applied to establish an outer limit line. Procedural approaches that have been proposed include: a decision of the CLCS on the deferral of the deadline for making submissions concerning the continental shelf in Antarctica; a decision by the Meeting of States Parties to the LOS Convention on such a deferral; a decision of the International Sea-Bed Authority (ISBA) not to consider

\section{Ibid.}

lbid.

90 This might be explained by a number of reasons. Australia was the first claimant state that would have had to make a submission to the CLCS before the decision on deferral of the 10-year time limit was taken by the Meeting of States Parties to the LOS Convention. The next state in line would have had to make a submission more than a year after Australia. Secondly, of all the claimant states, Australia has by far the longest Antarctic coastline and largest continental shelf beyond 200 nautical miles, implying that it has to gather more data than the other claimant states. Finally, other claimant states may prefer a different approach to deal with this issue, which may not require the collection of data. These states may assess differently the possible implications of not including information on the continental shelf of their Antarctic territories in a submission to the CLCS. As was noted above, the political geography of Antarctica also has an impact on the options available to different states under Annex I to the Rules of Procedure of the CLCS. 
applications for deep sea-bed mining in areas which form part of the Antarctic continental shelf; ${ }^{91}$ and the submission of information on the entire Antarctic continental shelf to the CLCS by the Antarctic Treaty Consultative Parties (ATCPs). ${ }^{92}$ A claimant state could decide to proceed unilaterally with a submission on its Antarctic continental shelf to the CLCS, complying with all the generally applicable requirements or decide not to include its Antarctic territories in a submission to the CLCS.

As far as the definition of the outer limit of the continental shelf is concerned, Orrego Vicuña has suggested a number of options, apart from applying the rules contained in Article 76 of the LOS Convention. As he points out, the express invocation of Article 76, which he considers as possibly the most appropriate solution, could present difficulties because of its linkage to the concept of coastal state jurisdiction. It would be possible to adopt alternative wording, which, while being consistent with the outer limit formula contained in Article 76 of the LOS Convention, would not make a direct reference to coastal state jurisdiction. The variation in the outer limit provisions of this Article is rejected as it would be likely to constitute a factor complicating the achievement of a compromise. A final alternative would be to establish an outer limit based on geographical coordinates which avoids the use of any wording that might compromise the positions of the claimant states and non-claimant states. ${ }^{93}$

It would be possible for the ATCM or the claimant states to adopt a decision concerning the outer limit of the Antarctic continental shelf. However, it seems unlikely that such an action in itself will satisfy claimant states that their position under the LOS Convention is safeguarded. If such a decision is not communicated in some way to the relevant institutions of the LOS Convention, it can be expected not to achieve the desired political and legal impact.

The involvement of the Meeting of States Parties to the LOS Convention or the ISBA in a decision directly addressing the continental shelf in Antarctica seems to have certain drawbacks. The Meeting of States Parties has already taken a decision on the general deferral of the 10-year time limit for making submissions to the CLCS. The Meeting could take a similar decision deferring submissions in respect of the Antarctic continental shelf. ATCPs may be hesitant about an involvement of the Meeting of States Parties to the LOS Convention

See Fact Sheet, note 56 above, p. 5. Similarly D. Vidas, in discussing the potentially conflicting regimes of the Madrid Protocol and Part XI of the LOS Convention, has suggested that a solution to that problem may be a decision of the ISBA exempting the Southern Ocean sea-bed from its competence to regulate mining activities, justified by the environmental sensitivity of this area (D. Vidas, note 33 above, p. 313). For questions that may arise in this connection see ibid., p. 314.

F. Orrego Vicuña, note 4 above, p. 116; A. Jackson (ed.), On the Antarctic Horizon; Proceedings of the International Symposium on the Future of the Antarctic Treaty System; Ushuaia, Argentina, 20 to 24 March 1995 (Consejo Argentino para las Relaciones Internacionales and Australian Antarctic Foundation, 1995), p. 49.

F. Orrego Vicuña, note 4 above, p. 116. 
because it may set a precedent for other decisions on Antarctica outside the framework of the ATS. Certain claimant states may consider that a decision of the Meeting of States Parties on the continental shelf in the Antarctic, as opposed to a decision on the procedure concerning the question of submissions under Article 76 generally, derogates from the sovereign rights they have over their continental shelf. Moreover, it cannot be excluded that the introduction of a proposal on such a decision would result in a discussion of matters related to the substantive regime of Antarctica, which is something the ATCPs probably would not like to see happening.

The decision on the 10-year time limit by the Meeting of States Parties indicated that this issue would remain in consideration. A further general deferral of the 10-year time limit, either by a further decision of the Meeting or other means, remains a possibility. This would be an attractive option for the Antarctic claimant states, as it does not require any discussion specifically related to the continental shelf in Antarctica. The different options for a deferral of the time limit have been set out in a background paper prepared by the Secretariat of the UN. These options might also be considered in connection with a deferral of submissions by states in Antarctica. ${ }^{94} \mathrm{~A}$ number of options consider the formal amendment of the Convention. It can be questioned whether such formal amendment would receive sufficient support from states without a continental shelf beyond 200 nautical miles, as these states have a limited interest in adhering to such an amendment. An amendment receiving only support from states with a continental shelf beyond 200 nautical miles may not serve its purpose or may never enter into force.

It seems less likely that the ISBA will be involved in this matter, both for legal and political reasons. A decision of the ISBA would either result in a moratorium on mining in certain areas or indicate a limit of the area under its jurisdiction. A moratorium on mining in areas which are landward of the outer limit of the continental shelf in Antarctica, would, at least from the perspective of the claimant states, imply a competence of the ISBA in respect of areas under national jurisdiction. ${ }^{95}$ The ISBA has not been accorded any competence over areas under national jurisdiction under the LOS Convention. Apart from the claimant states, other states may also reject any decision suggesting otherwise. Moreover, ATCPs in general are likely to reject such an approach as this matter in their view falls within the scope of the ATS, and not Part XI of the LOS Convention.

Another option would be for the ISBA to take a decision on the southern limit of the Area. A limit that would seek to delimit the Area from the continental shelf would result in similar objections as a moratorium on mining. The ISBA does not have any competence in respect of the definition of the

In addition, such a decision would not resolve the issue of the limit of the area concerned. 
Area. ${ }^{96}$ Coastal states generally are likely to resist any precedent that suggests the existence of such a competence. A definition of the southern limit of the Area by the ISBA that does not take into account the substantive rules of Article 76 does not seem readily available. The only obvious alternative, the parallel of $60^{\circ} \mathrm{S}$, being the limit of the Antarctic Treaty area, does not include certain areas that probably form part of the legal continental shelf of Antarctica under Article 76 of the LOS Convention to the north of this latitude. Any other definition of the southern limit of the Area, not linked to the outer limit of the continental shelf resulting from the application of Article 76 , would have to be generally to the north of $60^{\circ} \mathrm{S}$. This would exclude parts of the Area from the regime of both the ATS and the LOS Convention, making this a prima facie unattractive solution.

A final institution to deal with this matter under the LOS Convention would be the CLCS. This approach presents itself as the obvious choice as the CLCS has been designated under the Convention to deal with matters related to the establishment of the outer limits of the continental shelf beyond 200 nautical miles. The LOS Convention does not exclude states from making a joint submission to the CLCS and Annex I to the Rules of Procedure of the CLCS recognises this possibility explicitly. This offers the ATCPs (or the claimant states and other most directly interested states) the possibility of approaching the CLCS jointly over the implementation of the Article 76 of the LOS Convention. However, claimant states remain free to include information on their continental shelf in Antarctica in a submission that they make individually.

As was noted above, a proposal to the CLCS to take a decision on the deferral of submissions in respect of Antarctica was not accepted. This makes it unlikely that the CLCS would consider this approach in the future, especially as this falls outside its mandate and would be likely to create a tension with the Meeting of States Parties to the LOS Convention.

If a submission were to be made to the CLCS, either jointly or individually, it would have to be decided what kind of information to include. ${ }^{97}$ As was indicated above, the LOS Convention does not establish special rules for submissions in respect of the continental shelf involving territorial or maritime disputes, but its Article 311(2) might provide a basis for not submitting (all) information on the continental shelf in Antarctica to the CLCS. A report of the Secretary-General of the United Nations on Antarctica has indicated that the

96 The LOS Convention defines the Area as the sea-bed and ocean floor and its sub-soil beyond the limits of national jurisdiction. The establishment of these limits in accordance with Part VI of the Convention is the responsibility of the coastal state (LOS Convention, Arts. 1(1)(1) and 134). The absence of a role for the ISBA is confirmed by the fact that the Convention does not give it rights in the Area as such, but charges it to organise and control activities in the Area (ibid., Arts. 137 and 157; see also S. Mahmoudi, The Law of Deep Sea-Bed Mining (Stockholm, Almqvist and Wiksell International, 1987), p. 77).

97 The indication of alternative limits, not related to the outer limits of the continental shelf, in this case is excluded as it falls outside the competence of the Commission. 
Antarctic Treaty and other ATS instruments as such fall within the scope of this Article. ${ }^{98}$

A first question in respect of Article $311(2)$ is whether the obligation to submit information on the outer limits of the continental shelf alters the rights or obligations of states parties to the Antarctic Treaty. Secondly, it has to be established if the absence of a submission affects the enjoyment by other states parties to the LOS Convention of their rights or performance of their obligations under the Convention. As far as the first question is concerned, it could be argued that a submission would be contrary to obligations contained in Article IV(2) of the Antarctic Treaty. However, claimant states have taken the position that this provision does not exclude the establishment of maritime zones off their Antarctic territories. This makes its invocation in the present case difficult, as it could be taken to contradict the existing positions of the claimant states.

An alternative basis to invoke Article 311(2) might be the decision of the ATCPs concerning the definition of the continental shelf. As was noted above, the Final Act of the Fourth Special ATCM agreed that the extent of the continental shelf as referred to in Article 5(3) of CRAMRA would be determined by reference to the rules and criteria contained in Article 76, paragraphs 1 to 7 of the LOS Convention. This decision does not include a reference to Article 76(8), which deals with submissions by coastal states. This could be taken as a commitment of the ATCPs not to make use of the CLCS in establishing the outer limits of the continental shelf of territories inside the Antarctic Treaty area, ${ }^{99}$ which could be supported by the argument that a submission in respect of the continental shelf in Antarctica would go against the object and purpose of the Antarctic Treaty, as it would threaten to undo the balance of interests of claimant and non-claimant states contained in it, which is a fundamental aspect of this Treaty. ${ }^{100}$ In addition, it could be argued that a submission would go against the object and purpose of the LOS Convention in general and its Article 76 in particular. The Convention purports to establish a stable ocean regime and the procedure under Article 76 is intended to establish a stable boundary between the continental shelf and the Area. A submission in respect of the continental shelf of Antarctica can be expected to contribute very little to either of these objectives and may even have an adverse impact.

The second requirement of Article 311(2) of the LOS Convention is that not meeting the 10-year time limit for making a submission would not affect the

A/41/722 of 17 November 1986 , paras. 116-117.

99 The question exists if this decision only was applicable to the definition of the continental shelf under CRAMRA, or also binds the ATCPs generally. Actions taken by Australia in respect of the continental shelf of the AAT suggest the former. The absence of a reference to Art. $76(8)$ can also be explained by the fact that the LOS Convention at the time this decision was adopted (May 1988) had only been ratified by 35 states and the CLCS would only be established and become operative some time after the entry into force of the Convention. Moreover, most ATCPs, including most claimant states, had not yet become a party to the Convention in 1988 .

100 See also T. Scovazzi, note 9 above, p. 385. 
enjoyment by other states parties of their rights or the performance of their obligations under the Convention. The Convention, and especially the practice in its implementation, has created a mechanism for establishing the outer limit of the continental shelf, which may in some cases lead to an undefined period of time in which the outer limit of the continental shelf will not be established in accordance with Article 76. This fact alone suggests that the second requirement under Article 311(2) is met by the present case. ${ }^{101}$

The Rules of Procedure of the CLCS make special provision for situations involving land or maritime disputes. The Rules of Procedure do not allow a deferral of the submission of information in respect of the outer limits of the continental shelf, apart from cases involving the delimitation of continental shelf boundaries between states. ${ }^{102}$ As was argued above, the provision on delimitation can be considered to cover some and possibly all areas of continental shelf in Antarctica. Especially if no feasible alternatives are available, reliance on this provision could be used to defer submissions on the Antarctic continental shelf indefinitely. Although the CLCS is responsible for the application of Annex I in considering submissions, it seems unlikely that this would result in overruling the view of the coastal state that no submission is made "in order not to prejudice questions relating to the delimitation of boundaries between States".

There are a number of advantages to this approach for claimant states. States do not have to gather the data that would be required in connection with the establishment of the outer limit of the continental shelf in Antarctica. Secondly, states will not have to submit information on the outer limits to the CLCS, allowing a postponement of a decision on such controversial legal issues as the location of the baseline along the Antarctic coastline. ${ }^{103}$ Finally, as this approach is covered by the Rules of Procedure of the CLCS (and Article 9 of Annex II to the Convention) it prevents the argument that the coastal state has not complied with its obligations under Article 76 of and Annex II to the LOS Convention.

Another option that can be considered by a claimant state is to include

${ }^{101}$ See also infra the discussion on the implications of the absence of recommendations by the CLCS.

102 The reason for this distinetion is not altogether clear. At first sight it might seem that areas of continental shelf that need to be delimited between states do not border on areas beyond the limits of national jurisdiction. This means that the establishment of the extent of overlap of the continental shelf is a matter for the states concerned. However, in almost all cases in which a state has to delimit its continental shelf beyond 200 nautical miles in relation to a neighbouring state, there will also be a part of the shelf adjacent to the Area. The only exception to this is formed by sea-bed enclaves beyond 200 nautical miles which are completely comprised of legal continental shelf.

103 Most of the Antarctic coastline is permanently covered by ice. There does not exist any clear practice concerning the establishment of baselines along ice-covered coasts. A choice for one or another method would in certain cases have a significant impact on the location of the baseline (see further D.R. Rothwell, note 41 above, pp. 56-58; A. Watts, note 31 above, pp. 142-145). The establishment of (straight) baselines along the Antarctic coastline might also be protested as being contrary to Art. IV of the Antarctic Treaty (see further D.R. Rothwell, note 41 above, pp. 64-65). 
information in a submission to the CLCS setting out the particular legal regime of the Antarctic Treaty area and its implications for maritime jurisdiction. ${ }^{104}$ The coastal state could invite the CLCS to address this matter in the recommendations it shall make to that state. ${ }^{105}$ Such recommendations could make reference to the particular situation of the Antarctic and request the coastal state to make a revised or new submission within a reasonable time. ${ }^{106}$ To establish what is reasonable the specific situation in the Antarctic should be taken into account, implying that a reasonable time might cover at least the period the Antarctic Treaty remains in force.

The submission to the CLCS of all information that would be required for it to make a recommendation on the outer limit of the continental shelf of an Antarctic claimant state can also be considered. It seems unlikely that the ATCPs or the claimant states would be able to agree on a joint submission, due to the myriad of legal problems that would have to be resolved. A submission by an individual claimant state would be easier to prepare. However, it seems highly probable that other states would react to the submission, indicating the existence of a dispute in the sense of Annex I to the Rules of Procedure of the CLCS. It seems unlikely that all states involved would give their consent to the examination of the submission by the Commission. ${ }^{107}$ Examination of a submission resulting in recommendations by the Commission would imply a finding on inter alia the location of the baseline along ice-covered coasts. Such a clarification would be a serious blow to the approach of "constructive ambiguity", which is intended to prevent the need of conclusive findings on matters related to maritime jurisdiction. Even more importantly, it would strengthen the view of the claimant states that there are coastal states in Antarctica. The process of establishing outer limits under article 76 of the LOS Convention is based on this premise. A declaration that a submission is without prejudice to the position of states in respect of maritime jurisdiction in Antarctica would safeguard the position of states under the ATS, which in any case is also guaranteed by Article IV of the Antarctic Treaty. At the same time, a recommendation on the outer limits in Antarctica would still set a precedent with

${ }^{104}$ A drawback of this approach is that it is not, unlike the previous approach, sanctioned by the Rules of Procedure of the CLCS, which in case of disputes, other than those related to the delimitation of the continental shelf, require the submission of information on the outer limits of the continental shelf. In the previous case the state involved has complied with its obligations under Art. 76 of and Annex II to the LOS Convention. Whether that is also the case for the approach suggested here is not altogether clear. The fact that the CLCS did not agree to a deferral of submissions in regard of Antarctica when this matter was brought to its attention, suggests that the Commission might not be favourably disposed to this approach.

105 The formulation contained in Art. 76(8) of the LOS Convention is broad enough to allow such an approach. The Article provides that the CLCS is to make recommendations to coastal states "on matters related to the establishment of their continental shelf".

106 The possibility of a new or revised submission is envisaged in case the coastal state disagrees with the recommendations of the Commission (LOS Convention, Annex II, Art. 8).

${ }^{107}$ See also S.B. Kaye, note 10 above, p. 128. 
at least political and psychological implications, likely to have a negative impact on the ATS.

The fact that the Rules of Procedure exclude the examination of information on the outer limits of the continental shelf without the consent of all states concerned to a large extent neutralises the negative impact a submission might have on the ATS. After information has been submitted to the CLCS, its consideration will probable be deferred for an indefinite period of time. However, the outer limits proposed in the submission would be circulated to all member states of the United Nations, including states parties to the Convention, in order to make public the proposed outer limits of the continental shelf. ${ }^{108}$ Thus, even if a submission is not considered by the CLCS, the position of the claimant state will be widely publicised.

A final alternative for a claimant state would be to include no reference to the continental shelf in Antarctica in its submission to the CLCS. ${ }^{109}$ However, it does not seem likely that such an approach will be acceptable to all Antarctic claimant states, even though it would not prejudice their entitlement over the continental shelf. It would imply that a state has not complied with the provision on the 10year time limit of Article 4 of Annex II to the LOS Convention. This could exclude the possibility of a later submission. At least Australia seems thus far to have taken the position that the CLCS should in some way be notified of Australia's views on its continental shelf in Antarctica.

The continental shelf of a number of islands, which themselves are situated outside the Antarctic Treaty area, may extend into the Antarctic Treaty area. The continental shelf of these islands may overlap with the continental shelf of territories inside the Antarctic Treaty area. A submission in respect of these islands may, in this way, also raise questions in respect of the status of the Antarctic continental shelf. One option would be to exclude this part of the shelf or all of the shelf of the islands from the submission to the CLCS, with a reference to paragraph 3 of Annex I to the Rules of Procedure of the CLCS. ${ }^{110}$ This approach may still be open to objections from other states, as it can be seen, depending on the formulation employed, as a recognition of entitlement to continental shelf of territory in the Antarctic Treaty area. The state(s) making a submission might also use one of the options provided by paragraph 4 of Annex I to the Rules of Procedure of the CLCS. Such an approach links the submission

108 Rules of Procedure of the CLCS, Rule 49.

109 This situation differs from the one above involving the invocation of Art. 311(2) of the LOS Convention. In the latter case the coastal state would explicitly refer to its Antarctic continental shelf and indicate its reliance on Art. 311(2).

110 The continental shelf of Heard and McDonald Islands can only overlap with that of the AAT. Paragraph 3 of Annex I to the Rules of Procedure was not drafted to include internal administrative boundaries, as reference is to the delimitation of boundaries between states. However, the differences in the regimes under international law applicable to the maritime zones of Heard and McDonald Islands and the AAT suggest that a delimitation between both areas of continental shelf should nonetheless be accepted to fall under para. 3 of Annex I. 
for the island concerned even more closely to the question of entitlement to maritime zones of territory located in the Antarctic Treaty area.

\section{The Implications of the Absence of Recommendations of the CLCS}

If the CLCS is not a in position to make recommendations in respect of a part of the continental shelf, either because a state has made a partial submission or because not all states to a land or maritime dispute have given their prior consent, a state will not be able to establish the outer limits of the continental shelf on the basis of such recommendations.

A submission that has been made to the CLCS, but cannot be examined by it, must be considered to have prima facie implemented the relevant provisions of Article 76 of the LOS Convention in good faith. This would suggest that the outer limit lines contained in the submission can be employed by the coastal state as provisional outer limits of its continental shelf, pending the examination of the submission by the CLCS.

If the coastal state has not made a submission in respect of a part of its continental shelf beyond 200 nautical miles, it still can establish this outer limit on the basis of the rules contained in paragraphs 1 to 7 of Article 76 of the LOS Convention, either at the time it makes a submission for other areas, or at a later date, and apply these provisionally until it is in a position to make a submission to the CLCS on that part of its continental shelf. There is nothing in the LOS Convention indicating that such an approach is not permitted.

The location of the outer limit of the continental shelf of a state is of relevance to the ISBA and other states. The ISBA would be required to accept a provisional limit and probably also an indication of an area of interest, as it does not have any role in reviewing the limits of areas under national jurisdiction. ${ }^{111}$ In this sense there is no difference with, for instance, an outer limit at 200 nautical miles of an insular feature whose status under Article 121(3) of the LOS Convention is controversial. If a provisional limit has been established on the basis of Article 76 of the Convention, the uncertainty over the location of the boundary between the continental shelf and the Area would in principle only concern fringe areas.

Other states may protest a limit that has been provisionally established by a coastal state. The resolution of such a dispute in general may be difficult in view of its close linkage to the procedures under Article 76 of the LOS Convention, with the possible exception of cases in which the outer limit is clearly not established in conformity with Article 76.

For specific activities of states in Antarctic waters, the absence of final and binding continental shelf limits seems to have limited consequences. Activities of states participating in the ATS are governed in the first place by that regulatory

${ }^{111}$ See note 97 above. Cf. G.D. Triggs, note 10 above, p. 93. 
framework, in which the role of coastal state jurisdiction in general is of limited significance. No ATS instrument in force requires a definition of the outer limit of the continental shelf. For states outside the ATS, especially to the extent they reject the existence of coastal states in Antarctica, the continental shelf as such is nonexistent. Whether or not outer limits of this continental shelf are established will not have an impact on the approach of these states to activities in the area concerned.

\section{Conclusion}

The requirement to make a submission on the outer limits of the continental shelf beyond 200 nautical miles to the CLCS under Article 76 of the LOS Convention raises complex legal and political questions for claimant states and non-claimant states. They will have to decide on a course of action that safeguards the stability of the ATS and does not prejudice the rights of states under the LOS Convention in respect of their continental shelf. Most complications exist in respect of territories inside the Antarctic Treaty area. Submission for islands to the north of the Treaty area, which have a continental shelf extending into this area, probably can be made, making use of paragraph 3 or possibly paragraph 4 of Annex I to the Rules of Procedure of the CLCS. However, if a submission is made for the continental shelf of these islands, care should be taken to guarantee that the submission itself or the reactions it may provoke do not prejudice "constructive ambiguity" under the ATS.

This article has discussed a number of solutions in respect of the outer limit of the continental shelf of territories inside the Antarctic Treaty area. The analysis shows that the states collaborating in the ATS have been able to take into account developments in the law of the sea in respect of maritime jurisdiction without compromising the positions of the claimant states and the non-claimant states. The negotiations of CRAMRA resulted in agreement on a limit of the Area in the Antarctic Treaty area. This definition only concerned general principles and did not imply agreement on the actual application of Article 76 of the LOS Convention in this region.

Claimant states have not refrained from establishing maritime zones for their Antarctic territories, although their approach has differed. This implies that not all states may have similar views on how to deal with Article 76 . Some states may feel they have to inform the CLCS in some way of their views on the continental shelf in Antarctica, but others may not consider this to be necessary.

The main problem of a submission to the CLCS would be that its consideration would give an unprecedented recognition to the position of the claimant states concerning maritime zones. A recommendation on the outer limits of the continental shelf of Antarctic territories could seriously damage "constructive ambiguity", one of the cornerstones of the stability of the ATS. Non-claimant states have protested assertions of coastal state jurisdiction by 
claimant states. This makes it unlikely that they will let a submission to the CLCS pass by uncontested.

A number of solutions have been considered to deal with this issue. Letting the time limit for making a submission lapse does not seem an acceptable solution for all Antarctic claimant states, although this would not have consequences for the entitlement to the continental shelf as such, but only for the establishment of its outer limit. This approach would entail non-compliance with Article 4 of Annex II to the LOS Convention. This could exclude the possibility of a later submission.

It has been suggested that three institutions within the framework of the LOS Convention might be relevant for dealing with the outer limit of the continental shelf of Antarctic territories, namely, the Meeting of States Parties, the ISBA, and the CLCS. There exist legal and political arguments suggesting that the former two bodies are not likely to be approached to deal specifically with this issue. For one thing, this might give bodies outside the ATS a certain say over issues concerning the ATS, and already for this reason ATCPs might oppose these options. The Meeting of States Parties could consider a further general deferral of the time limit for making submissions to the CLCS. This would provide states in the Antarctic with further time to come up with a solution for their specific dilemmas. As this option does not require a discussion of Antarctic issues, it may be the preferred option of the states participating in the ATS, including the claimant states. The discussion of the deferral in 2001 did touch upon certain difficulties posed by the Polar environment. Such general considerations may also be employed by (claimant) states in any future discussion without the risk of directly raising the issue of Antarctica. The deferral of the time limit decided upon in 2001 has most likely taken some of the pressure off the states dealing with continental shelf issues in Antarctica.

A considerable number of approaches involving the CLCS has been considered. One option would be for a state to invoke Article 311(2) of the LOS Convention to postpone a submission concerning its Antarctic continental shelf. The conditions for applying Article 311(2) would seem to be present in this case. However, the position of at least some of the Antarctic claimant states in the past indicates that invocation of this Article could suggest inconsistencies in their position concerning maritime jurisdiction.

Annex I to the Rules of Procedure of the CLCS offers states a number of options to deal with submissions involving maritime or territorial disputes. As the analysis points out, the Annex is of relevance for submissions in respect of the continental shelf of Antarctic territories. Its paragraph 3 seems to offer states the possibility of deferring a submission for this part of their continental shelf for an indeterminate period of time in order not to prejudice questions related to the delimitation of continental shelf boundaries between states. This paragraph can be argued to be applicable to all of the Antarctic continental shelf. Under this option states do not have to gather data in preparation of a submission but all the same have complied with their obligations under the LOS Convention. 
Another advantage of paragraph 3 is that it does not imply the recognition of the existence of a territorial dispute. This makes it an attractive option for those claimant states that consider that there is no dispute over their Antarctic territory.

Annex I to the Rules of Procedure does not exclude the submission of information on an Antarctic continental shelf, but makes it highly unlikely that such a submission will be considered by the CLCS. This implies that the negative consequences of a submission for "constructive ambiguity" under the ATS will be limited. The CLCS will not be forced to make a recommendation in which it would have to address controversial issues related to maritime jurisdiction in the Antarctic Treaty area, but the submission can be shelved for an indeterminate period of time.

The absence of final and binding limits will not have grave consequences for either the claimant states or other states under the ATS or the LOS Convention. Such absence could lead to difficulties in areas where activities on the continental shelf or the Area are imminent. However, this does not seem to be the case for the sea-bed off the Antarctic continent. Moreover, activities to a large extent can be regulated in the framework of the ATS in the absence of a final and binding limit of the continental shelf.

The overall conclusion of this analysis is that solutions which result in the deferral of the establishment of the limits of the continental shelf in Antarctica are acceptable. These solutions seem to offer the best guarantee for maintaining "constructive ambiguity" and safeguarding the rights of claimant states in respect of the outer limits of their continental shelf under the LOS Convention. However, as there a number of options in this respect and claimant states (and non-claimant states) may evaluate the propriety of these options differently, it may take considerable effort to arrive at a compromise on which option(s) to pursue. 


\section{Appendix}

Rules of Procedure of the Commission on the Limits of the Continental Shelf [...]

\section{Rule 45}

Submissions in case of a dispute between States with opposite or adjacent coasts or in other cases of unresolved land or maritime disputes

1. In case there is a dispute in the delimitation of the continental shelf between opposite or adjacent States or in other cases of unresolved land or maritime disputes, submissions may be made and shall be considered in accordance with Annex I to these Rules.

2. The actions of the Commission shall not prejudice matters relating to the delimitation of boundaries between States.

$[\ldots]$

\section{Annex I}

Submissions in case of a dispute between States with opposite or adjacent coasts or in other cases of unresolved land or maritime disputes

1. The Commission recognizes that the competence with respect to matters regarding disputes which may arise in connection with the establishment of the outer limits of the continental shelf rests with States.

2. In case there is a dispute in the delimitation of the continental shelf between opposite or adjacent States, or in other cases of unresolved land or maritime disputes, in relation to the submission, the Commission shall be:

(a) Informed of such disputes by the coastal States making the submission;

(b) Ensured by the coastal States making the submission to the extent possible that the submission will not prejudice matters relating to the delimitation of boundaries between States.

3. A submission may be made by a coastal State for a portion of its continental shelf in order not to prejudice questions relating to the delimitation of boundaries between States in any other portion or portions of the continental shelf for which a submission may be made later, notwithstanding the provisions regarding the ten-year period established by article 4 of Annex II to the Convention.

4. Joint or separate submissions to the Commission requesting the Commission to make recommendations with respect to delineation may be made by two or more States by agreement:

(a) Without regard to the delimitation of boundaries between those States; or

(b) Having indicated by means of geodetic coordinates the extent to which a submission is without prejudice to the matters relating to delimitation of boundaries with another or other States Parties to this Agreement.

5. (a) In cases where a land or maritime dispute exists, the Commission shall not examine and qualify a submission made by any of the States concerned in the dispute. However, the Commission may examine one or more submissions in the areas under dispute with prior consent given by all States that are parties to such a dispute.

(b) The submissions made before the Commission and the recommendations adopted by the Commission thereon shall not prejudice the position of States which are parties to a land or maritime dispute. 
6. The Commission may request a State making a submission to cooperate with it in order not to prejudice matters relating to the delimitation of boundaries between opposite or adjacent States. 